\title{
Links Maps - Inquiry Learning (LMIL) Model to Improve Physics Thinking Ability
}

\author{
Salis Ahda \\ Teacher of SMAN 4 Malang
}

\begin{abstract}
This study aimed to develop link maps-inquiry learning (LMIL) model. The research design referred to Research \& Development, which consisted of preliminary studies, model development, and model test. The development Products were (1) theoretical framework, (2) syntax, (3) syllabus (4) lesson plan, (5) materials, (6) student worksheets, assessment tools, and link maps-inquiry learning model (LMIL model). Validation result showed that LMIL model was valid and worth for learning. The effectiveness test of LMIL model was done in class XI SMAN 8 Malang with a quasi-experimental research design. LMIL model was applied in the experiment class and direct learning was applied in the control class. The result of effectiveness test showed that LMIL model was effective to improve students' physics thinking ability. The students responded that LMIL model was interesting, fun, developing their understanding, cooperation skills, and improve the spirit of learning physics. LMIL Model had an impact on students' thinking ability, significant construction process, scientific thinking skill, and cooperative skill.
\end{abstract}

Keyword: learning model, link maps-inquiry, thinking ability

\section{Introduction}

A lot of researches related to the physics learning with inquiry had been done (Wenning, 2005a; 2005b; Ali M, 2009; Wash \& Sattes, 2005; Wee, et al, 2007; Lawson, 1995). Wenning (2005a) stated that teachers would be able to carry out physics learning effectively if they invited students to conduct an investigation of the material being studied. Therefore Wenning (2005b) emphasized that inquiry learning was essential to improve student achievement. Ali M (2009) practiced hypothetical inquiry learning to secondary school students in Pakistan for heat and temperature material. The students were encouraged to make a hypothesis before making an experiment to solve a problem. Walsh \& Sattes (2005) stated that the inquiry tended to challenge students to think about the concepts of physics being studied.

Wee et al (2007) found that there were still frequent obstacles in implementing the inquiry effectively and efficiently. Application of inquiry often took a lot of time. Ali M (2009) argued lack of time in inquiry learning happened because of the difficulties in the process of bringing the physics concept from the experimental to mathematical equations. Most trials are still limited to attest the enactment of theory/concept, rather than on problems solving development associated with the concept/theory. Many students find a difficulty when they try to solve the problem developed from the theory associated with mathematical equations. The difficulty mainly happens when they link one concept to another one or when linking one theory to another one.

Wee et al (2007) suggest teachers about the three important things in applying inquiry; they should understand the nature of the inquiry, must have a sufficient understanding about the structure of the knowledge being studied, and must be skilled in inquiry teaching techniques. To help students who have difficulty in linking one concept to another concept or from one theory to another theory in physics, Lindstrom (2010) and Hao Kuan (2010) offer to use Link Maps. Lindstrom helps first-year student majoring in physics by providing scaffolding using the link maps.

Link maps differ from concept maps and knowledge maps (a map of knowledge). Lindstrom (2010) describes link maps as follows.

Link Maps appear similar to concept maps owing to their colorful non - linear representation of subsets of domain knowledge. However, this is a superficial comparison and does not reflect the ideas underlying their invention nor their theoretical foundation. Concept maps and knowledge maps generally focus on a myriad concepts and associations and have specific sets of rules for creation). Link Maps, on the other hand, were specifically developed for physics in the which there are relatively few central concepts - the challenge in learning this unique discipline is not the number of concepts to be learnt but the number of associations (links) to be formed.

Link maps appear similar to the representation of a concept map, but the underlying ideas are different. Concept map and map knowledge generally focus on various concepts and associations and also have a number of special rules to make it. On the other hand link maps, are specifically developed for physics where there are few central concepts. The emphasis is not on a number of concepts that must be learned but on a number of links (links) that will be established. 
Link maps were based on cognitive load theory. There are three (3) types of cognitive load theory, namely: Intrinsic load, germane (relevant) load, and extraneous (irrelevant) load (Plass, Moreno, Brunken, 2010; Lindstrom, C. 2010; Hao Kuan, NC 2010). Intrinsic load is associated with the complexity of the material learned by the students. Intrinsic load (the complexity of the material) can be managed in a way to be more simple and easily learned by the students. Germane load relates to how the strategy of material presentation is done by teachers to facilitate student learning. The strategy used by the teachers needs to be adapted to the characteristics of the material. Extraneous load is an external load that disrupts the learning process of students, such as information from teachers that is not relevant to the material studied. In this case, learning can be effective if germane load is increased, extraneous load is reduced, and the instrinsic load is properly managed.

Link maps as one of the forms in packing material is a clearer linkage between concepts and simpler to understand the material, and also reducing the information that is not relevant (Lindstrom, 2010) because link maps can help students who have a difficulty in learning physics (Kuan Hao, 2010). In his research, Kuan (2010) handled the students who had a difficulty in learning physics by applying link maps.

To improve the effectiveness of learning inquiry, the three cognitive loads (instrinsic, germane, and extraneous load) need to be managed well by using the link maps. In this regard, this study developed inquiry learning model with the presentation of the material and its gain using link maps, hereinafter called Link mapsinquiry Learning Model. Inquiry was focused on the discovery of the concept. Link maps were used to establish the relationship between concepts or between theories in order to solve the physics problems and increase the students' thinking skill.

\section{Theoretical Framework}

Links maps-inquiry learning (LMIL) model is carried out by combining Inquiry learning and link maps strategy. Inquiry learning is used to build students' understanding of the physics concepts, so physics material is meaningful for students. In inquiry, the students build knowledge by conducting experiments so that the physics material is not abstract anymore. Link maps strategy is used to enhance students' thinking skills. In link maps strategy, students create linkage map between concepts with a description of the relationship between the concepts. Furthermore, the linkage is used to solve the problems associated with the material being studied.

Inquiry learning has syntax consisted of four (4) steps (Joyce B, Weil M., \& Calhoun, E, 2014). First, confrontation with problem, in this stage the teacher presents the problem and explains the inquiry procedure to students. The problem form needs to be adjusted to the student's knowledge. The problem presented must be an event that can stimulate the intellectual activity of students. Second, experiment; students conduct experiments by putting new things (variables) and see if there is a change. The experiment stage has two functions, namely exploration and direct test. In exploration, students change a few things and see what happens, whereas in direct test students conduct a test. Third, data organizing, students organize the data obtained from the experiment results. The fourth, data analysis and conclusion, students are asked to analyze the data to make a conclusion to the problems or questions presented.

Link maps strategy is specifically developed for physics in which there are central concepts relatively having little emphasis, not a concept to be learned, but a number of links that will be formed (Lindstrom, 2010). In link maps, links between concepts, between theories, between physics material and their links explanation are created. Students will easily learn the concepts of physics and easily improve their thinking skills. Link maps will also make students easy to solve the problem because the students "really" understand the material being studied and can make a relationship between the problem that is being studied and another underlying problem.

Further Plass, Moreno, and Brunken (2010) explain that in theory of cognitive load, there are three (3) cognitive loads that affect the teaching learning process, namely instrinsic load, germane load, and extraneous load. Instrinsic load relates to the complexity and material meaningfulness for students. Germane load associates with the strategy of material presentation so that it is easily understood by the students. Extraneous load relates to the information that is not relevant (disrupt) that happens in the learning process.

To make the learning effective, the three cognitive loads must be managed properly: germane load should be increased, extraneous load is reduced, and instrinsic load is properly regulated.

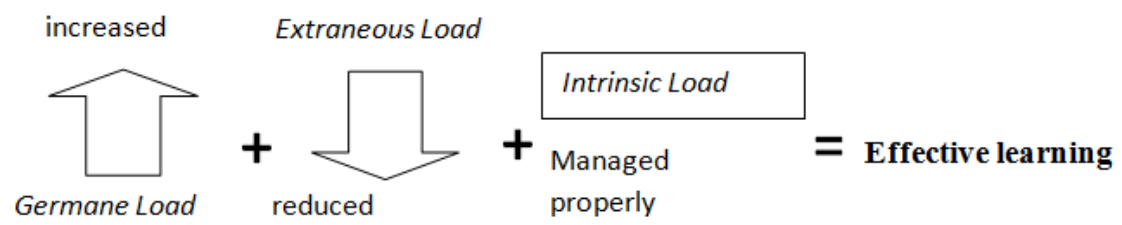

Figure1. Effective Learning process (Adopted from Lindstrom, 2010) 
The role of inquiry in LMIL model is to improve germane load and reduce extraneous load. In inquiry, the learning is designed to engage students optimally, ranged from problem orientation, problem deepening, practice implementation, to making conclusions. In this case the students are empowered to construct the concept and solve the problem through practice activities. It means germane load will increase. Furthermore, inquiry activities are equipped with a practical guide that provides useful information for students in conducting the activities. In this regard, activities and information that deviate from the learning objectives will be very little. In other words, a reduction in extraneous load happens.

Instrinsic load management is done by creating link maps. Presentation of momentum material using the link maps facilitates students in studying it easily. In this case, the intrinsic load can be managed simply by linking inter concept - theory - problem, so that the material becomes meaningful, easier to understand, and easier to remember. The theoretical framework that underlies the emergence of LMIL models can be described as Figure 2.

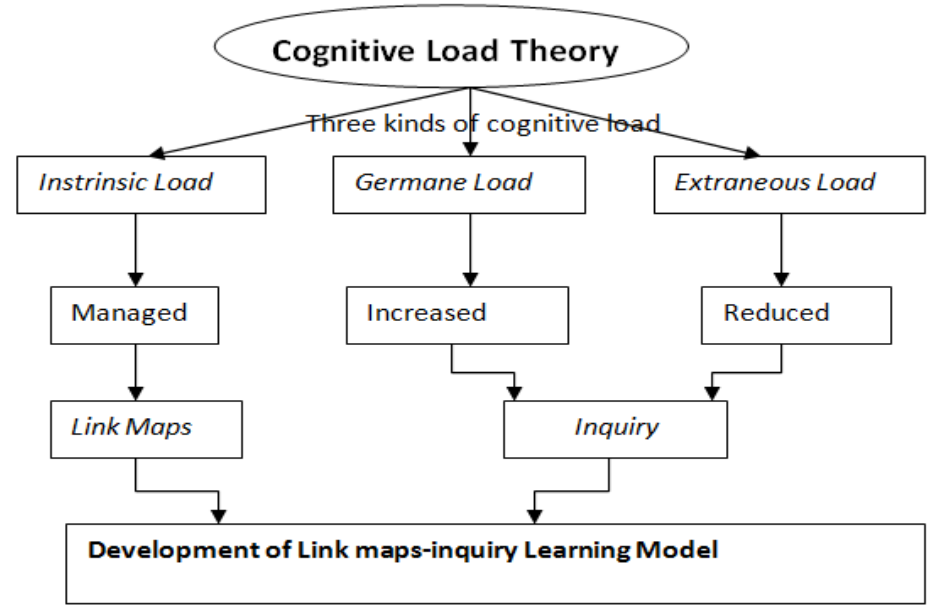

Figure 2 Theoretical Framework of LMIL Model

Based on the theoretical framework, syntax of LMIL model is developed: (1) the presentation of the problem, (2) experiment, (3) data organizing, (4) data analysis, (5) preparing link maps of experiment results, and (6) problem solving. Description of phases of syntax LMIL model is presented in Table 1.

Table 1: Syntax of LMIL Model

\begin{tabular}{|c|c|c|}
\hline Phases Model LMIL & Teacher Activity & Student Activities \\
\hline Presentation of the problem & $\begin{array}{l}\text { Delivering the problems associated with the } \\
\text { material to be learned. } \\
\text { Building students' reasoning by asking questions } \\
\text { related to the possibility of the material in life }\end{array}$ & $\begin{array}{l}\text { Students pay attention on the } \\
\text { problems given by the teacher. } \\
\text { Students answer questions asked by } \\
\text { the teacher. }\end{array}$ \\
\hline $\begin{array}{l}\text { Implementation } \\
\text { Experiments }\end{array}$ & $\begin{array}{l}\text { Setting up a practical work guide } \\
\text { Accompanying the students do a practical work }\end{array}$ & $\begin{array}{l}\text { Students do lab activities in } \\
\text { accordance with the instructions } \\
\text { provided by the teacher. }\end{array}$ \\
\hline Data Organizing & $\begin{array}{l}\text { Directing the interpretation process and recording } \\
\text { data } \\
\text { Accompanying the students to acquire the data } \\
\text { carefully }\end{array}$ & $\begin{array}{l}\text { Students gather data and take notes in } \\
\text { a table of observation }\end{array}$ \\
\hline Data analysis and conclusion & $\begin{array}{l}\text { Directing students in analyzing the data } \\
\text { Encouraging students to draw conclusions } \\
\text { Providing scaffolding for students who have } \\
\text { difficulty }\end{array}$ & $\begin{array}{l}\text { Students analyze the data as the } \\
\text { instructions of practice work. } \\
\text { Students make conclusions } \\
\text { Students who find difficulties ask for } \\
\text { help to the teacher }\end{array}$ \\
\hline Link maps Making & $\begin{array}{l}\text { Asking students to make link maps based on the } \\
\text { results of practical work } \\
\text { Helping students prepare link maps }\end{array}$ & $\begin{array}{l}\text { Students create link maps based o } \\
\text { the result of practice work } \\
\text { Students who find difficulties in } \\
\text { making the link maps ask for help to } \\
\text { the teacher }\end{array}$ \\
\hline $\begin{array}{l}\text { Application of Concepts and } \\
\text { problem solving }\end{array}$ & $\begin{array}{l}\text { Giving the problems associated with the materials } \\
\text { to be completed by students } \\
\text { Helping students to solve problems }\end{array}$ & $\begin{array}{l}\text { Working on issues related to the } \\
\text { material learned }\end{array}$ \\
\hline
\end{tabular}

In developing LMIL model it is equipped with a support system, the principles of management and social systems (presented in Figure 3). Support system implementation of LMIL model includes teaching materials (students' book and teachers' guidance), student worksheet, assessment tools, syllabus and lesson 
plan. Management principles in LMIL model include: (1) providing learning resources, (2) emphasizing cooperation, (3) giving scaffolding and (4) respecting and motivating. Teachers must provide learning resources needed. They include: the student books, worksheets, and reference books. Teachers need to emphasize and create a cooperation situation between students and interaction between teacher-student and student - student. Teachers also must check and serve students who have a difficulty and provide a help (scaffolding). In learning process the teacher must always respect the opinion / ideas of students and motivate students so that students can learn optimally.

Social system established in the application LMIL model includes: (1) cooperation, (2) freedom of speech, (3) responsibility, and (4) degree equality. In a learning process social situation is established for mutual cooperation within the group and between groups. Freedom of speech is an important part of the social system to develop students' thinking and courage of giving ideas. In the application of LMIL model a social system is established to be responsible in carrying out learning and practice work. The social system in the class is also created to make not discriminate race, ethnicity, religion and ability. To create this condition, forming random and heterogeneous discussion groups is carried out.

Support systems, management principles, and social systems are created. They are expected to bring instructional impact and accompaniment impact. Instructional impacts expected include: (1) the ability to think, (2) knowledge construction, (3) cooperative skills, and (4) scientific thinking attitude. Implementation of LMIL model delivers students to construct knowledge significantly. The students do the learning process by helping each other (cooperative), and in practice work they are directed to carry out scientific activities, so attitudes of scientific thinking is formed. With this process, it is expected to have an impact on students' thinking skill.

The accompaniment impact of LMIL model implementation includes: a positive attitude towards physics and students' independence. With fun and challenging learning process, students will feel that physics is a useful and fun lesson. With practice work and problem solving, students will be accustomed to be independent.

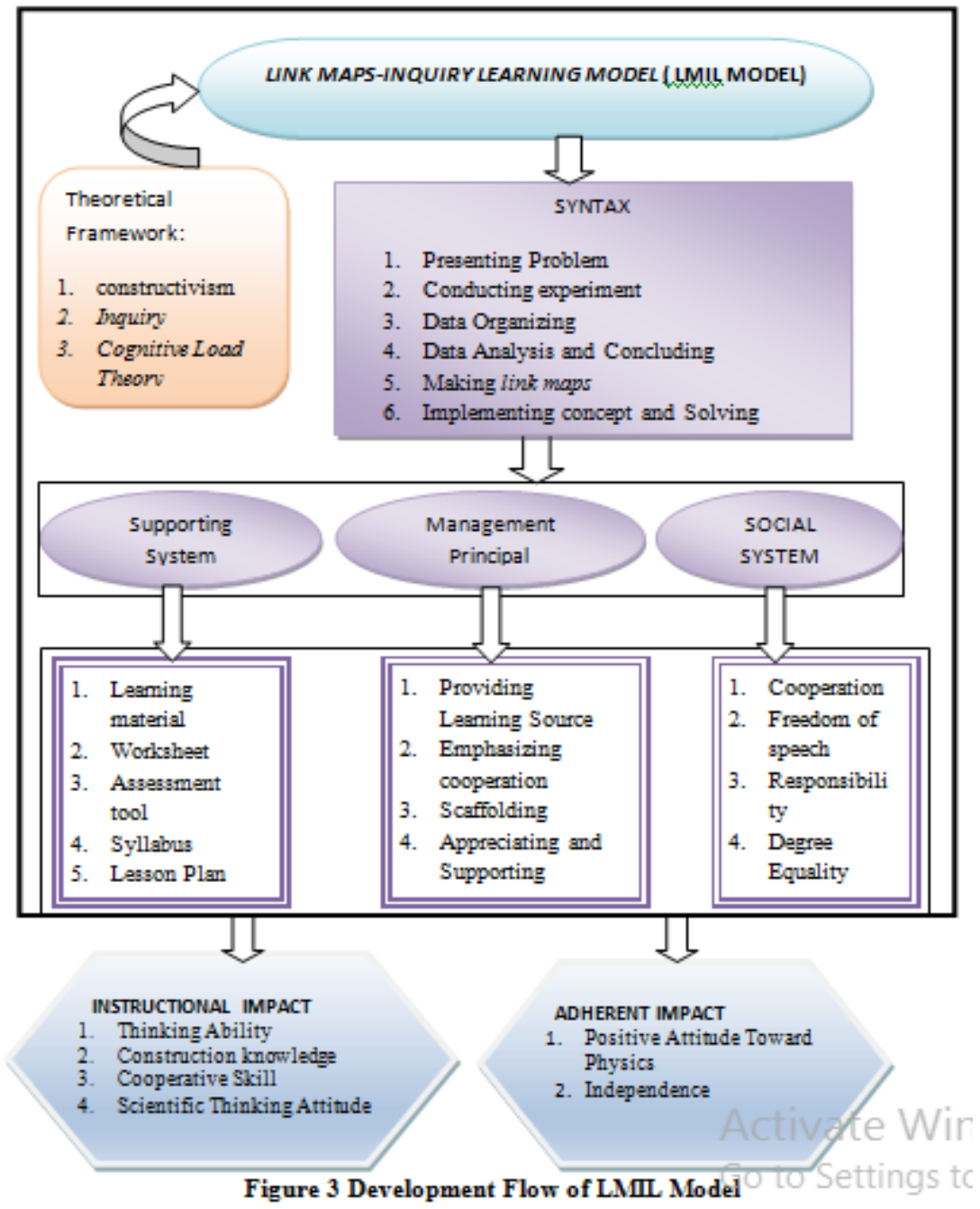




\section{Research Method}

LMIL model development design referred to the Research \& Development. The procedure of LMIL model development is presented as Figure 4.

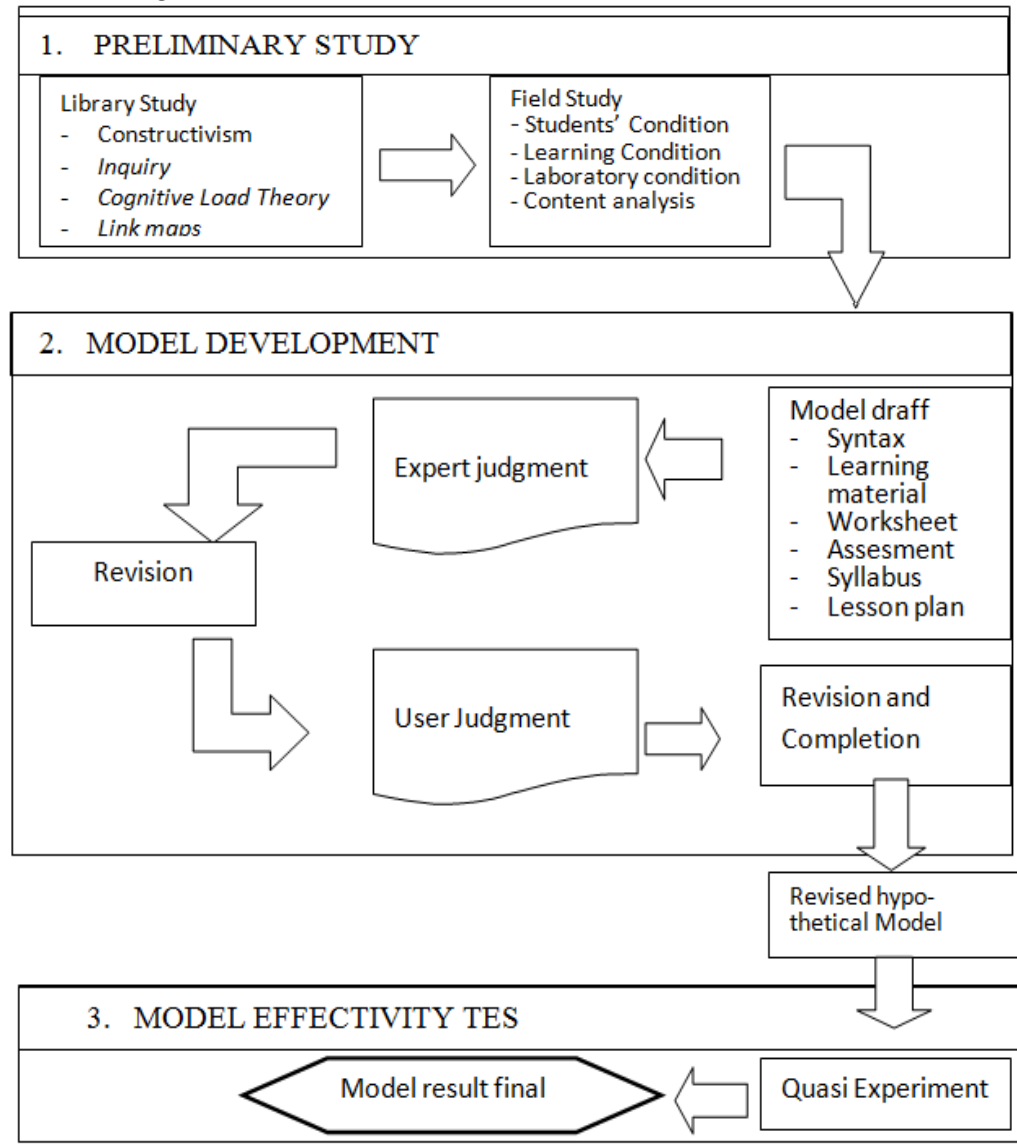

Figure 4 Procedure of Model Development

Preliminary study was carried out in the two forms of activities, library research and field study. Preliminary study was used to establish a theoretical framework that could be used as a reference in developing the learning model. Model development was done by arranging syntax, syllabus, lesson plan, teaching materials, student worksheets and assessment tools. The result of the model development was validated by experts and users, so hypothetical model was obtained. The effectiveness test design of hypothetical LMIL model used was quasi-experiment. To determine the effectiveness of LMIL model, different test of average (t-test) was done.

In the effectiveness test of LMIL model, the instructional and accompaniment impacts were also examined. Instructional impact includes: thinking ability, construction of knowledge, cooperative skills, and attitudes of scientific thinking. Adherent impact includes: a positive attitude towards physics and independence.

\section{Results/Findings}

The main products in this model development were theoretical framework, syntax, teaching materials, student worksheets, assessment tools, syllabus, and lesson plan. The theoretical framework was built based on inquiry learning and cognitive load theory, particularly the link maps. Syntax was constructed based on theoretical framework. Teaching materials, student worksheets, assessment tools, syllabus and lesson plan were developed with reference to the LMIL model syntax and the development results were validated by expert and user. The validation results of Syllabus and lesson plan are presented in Table 1.

Table 1 Validation Results of syllabus and LMIL Model Lesson Plan

\begin{tabular}{|l|l|l|l|l|l|l|l|}
\hline \multirow{2}{*}{$\begin{array}{l}\text { Validation } \\
\text { Component }\end{array}$} & \multicolumn{2}{|l|}{ Expert Judgment } & \multicolumn{2}{|c|}{ Users Judgment } & \multirow{2}{*}{ Conclusion } \\
\cline { 2 - 6 } & Expert 1 & Expert 2 & User 1 & User 2 & User 3 & Average & \\
\hline Syllabus & 3.625 & 3.625 & 3,875 & 3,875 & 3.625 & 3.725 & Valid \\
\hline lesson Plan & 3,556 & 3,667 & 3.889 & 3.778 & 3,667 & 3.711 & Valid \\
\hline
\end{tabular}


LMIL model syllabus developed is valid with an average score $=3.725$ (Table 1). Lesson plan of LMIL model developed is valid with an average score $=3.711$ (Table 1). It could be concluded that the syllabus and lesson plan were in accordance with the syntax of LMIL model.

Validated teaching material was student book. Student book already included student worksheet, summary of the material, concept map, link maps, and the application of the concept. The result of instructional materials assessment done by expert and user is presented in Table 2.

Table 2 Result of Instructional Materials Validation of LMIL Model

\begin{tabular}{|l|l|l|l|l|l|l|l|}
\hline \multirow{2}{*}{$\begin{array}{l}\text { Validation } \\
\text { Component }\end{array}$} & \multicolumn{2}{|l|}{ Expert Judgment } & \multicolumn{2}{l|}{ Users Judgment } & \multirow{2}{*}{ Conclusion } \\
\cline { 2 - 6 } & Expert1 & Expert2 & User1 & User2 & User3 & Average & \\
\hline $\begin{array}{l}\text { Front page } \\
\text { Images of Contents / }\end{array}$ & 3.25 & 3.25 & 3.25 & 3.50 & 3.50 & 3.35 & Valid \\
\hline $\begin{array}{l}\text { Learning Outcome } \\
\text { Indicators }\end{array}$ & 3.60 & 2.00 & 3.50 & 3.00 & 2.00 & 2.30 & valid enough \\
\hline Content advisability & 3.43 & 3.57 & 4.00 & 2.57 & 3.43 & 3.40 & Valid \\
\hline $\begin{array}{l}\text { Content } \\
\text { Presentation }\end{array}$ & 3.22 & 3.67 & 4.00 & 3.11 & 3.56 & 3.51 & Valid \\
\hline $\begin{array}{l}\text { Student's } \\
\text { Sheet }\end{array}$ & 3.40 & 4.00 & 3.80 & 3.40 & 3.40 & 3.60 & Valid \\
\hline Summary & 3.00 & 3.50 & 4.00 & 3.00 & 3.50 & 3.40 & Valid \\
\hline Concept map & 3.00 & 3.00 & 3.50 & 3.50 & 3.50 & 3.30 & Valid \\
\hline Link Maps & 3.00 & 3.00 & 4.00 & 4.00 & 3.50 & 3.50 & Valid \\
\hline Concept Application & 3.75 & 3.25 & 4.00 & 3.25 & 3.75 & 3.60 & Valid \\
\hline Glossary & 4.00 & 4.00 & 4.00 & 3.00 & 3.00 & 3.60 & Valid \\
\hline Bibliography & 4.00 & 4.00 & 3.00 & 4.00 & 4.00 & 3.80 & Valid \\
\hline
\end{tabular}

Teaching material of LMIL model developed was valid with an average score $=3.416$ because it deserves used for learning. For the effectiveness test of LMIL model, the initial ability of students was measured using pretest. The comparison test result of students' initial ability was performed using t-test. The result obtained was $\mathrm{t}_{\text {counting }}=0.586<\mathrm{t}_{\text {table }}=2.00$ with significant level of $5 \%$. It could be concluded that there was no significant difference in students' initial ability of both classes.

Comparison test of final capability was conducted by t-test to post-test scores. The result obtained was $\mathrm{t}_{\text {counting }}=2.81>\mathrm{t}_{\text {table }}=2.00$ with significant level of $5 \%$. It could be concluded that there was a significant difference in students' final ability of both classes. The average scores of the students in the experimental class taught with LMIL model is 81.09 higher than the average scores of control class taught with direct instruction = 73.94. It meant that LMIL model was effective to improve students' physics thinking ability.

91.6\% of students gave positive response to LMIL model. Most students $(94.00 \%)$ had very good impression on the implementation of learning with LMIL model.

\section{Discussion}

The application of LMIL model formed five (5) characteristics: interpersonal, understanding, inquiry, link maps, and construct with the relationship as shown in Figure 5.

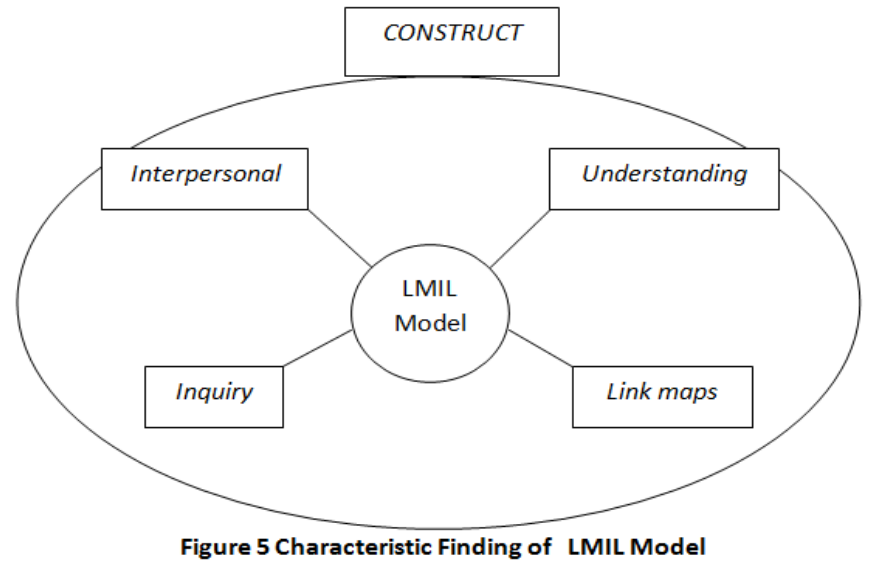

According to Silver et al (2007) the tendency of each learning conducted by teachers could be drawn in shaping students' learning behavior, called learning style. Learning style was grouped into four (4) categories: mastery, understanding, interpersonal, and self-expressive. 
The first characteristic was the interpersonal LMIL model. Interpersonal orientation was to grow the relationship between one student and another student (or with people in community). In interpersonal, students were conditioned to learn by helping each other. Knowledge construction process happened because there was the interaction of the students' thinking from one student to the other students. In LMIL model, learning process in a group was one of the characteristics. The activities ranged from experiments to draw up link maps were done cooperatively among students in the group.

The second characteristic was understanding. According to Silver et al (2007), the orientation of understanding was to develop the students' ability to reason, use evidence, and think logically. In this case curiosity was developed, so they could use logical reason to argue and find ideas based on the ideas learned. In LMIL model, logical reasoning of students was developed by developing the adherent questions in order to construct knowledge.

The third characteristic was inquiry. In the implementation of LMIL model, inquiry was one of the main activities. Students constructed momentum and impulse knowledge through experiments conducted structurally. Inquiry activities became the main characteristic because the inquiry had many advantages as it had been expressed by many experts (Wening, 2005a; 2005b; Ali M, 2009; Wash \& Sattes, 2005; Wee, et al, 2007; Lawson, 1995).

The fourth characteristic was link maps. Link Maps characteristic was very important in the application of LMIL model, especially in forming the knowledge scheme of momentum and impulse. Knowledge constructed from adherent question activities, inquiry, to cooperative learning was encapsulized into knowledge interrelated after link maps.

The fifth characteristic was construct. In the application of LMIL model, all processes that were carried out led to a construction of students' knowledge. Therefore the knowledge construction overshadowed the four other characteristics (Figure 5.1). In accordance with the theory of constructivism, that learning is a process of constructing knowledge, constructing knowledge can be through the process of social interaction and through individual construction. Construction through social interaction is called social constructivism pioneered by Vygotsky while the construction done individually called personal constructivism pioneered by Piaget.

\section{Conclusion}

The Results of LMIL model development included: (1) syntax, syllabus, lesson plan, and assessment tools; (2) teaching materials called student book consisted of student worksheets and practice work guidelines, a summary of the material, concept map, and link maps; and (3) the teacher book consisted of syntax, syllabus, lesson plan, assessment tools, and student book. The validation results of conformity between syllabus and lesson plan with syntax of LMIL model were that: syllabus average was 3.725 with valid criteria, and the average of lesson plan was 3.711 with valid criteria. The validation result of student book was that: the average score was 3.416 with valid criteria and deserved to be used for learning.

There were significant differences in students' thinking skill using LMIL learning model compared with the students thinking skill that did not use LMIL model or direct learning. In this case, the average scores of students taught with LMIL model significantly higher than that of students that were not taught not using LMIL model.

\section{References}

[1]. Joyce B, Weil M., \& Calhoun, E., 2014. Model of Teaching (9th Edition). New York. Pearson Education.

[2]. Kuan Hao, NC, 2010. Integrating multimedia into maps link: An Investigation School of Physics. Sydney: University of Sydney.

[3]. Krathwohl, R.D., 2002. A Revision of Bloom's Taxonomy: An Overview. Theory into Practice. Volume 41 Number 4: pp. $212-218$

[4]. Krulik, R \& Milou, 2003. Teaching Mathematics in Middle School. A Practical Guide. New York: Pearson Education.

[5]. Lawson, AE 1995. Scince Teaching and the Development of Thinking. California: Wadsworth Publishing Company.

[6]. Lindstrom, C. 2010. Link Maps and Map Meeting: A theoretical and experimental case for stronger scaffolding in first Year University physics education PhD thesis, School of Physics.

[7]. Lindstrom, C., \& Sharma, DS 2009. Link Maps and Maps Meeting: Scaffolding Student Learning. Physics Education Research. Vol 5. Number 010102 (2009)

[8]. Ali, Manzoor, 2009. Teaching of heat and temperature by hypothetical inquiry approach: A sample of inquiry teaching .Journal online Physics Teacher Education Vol 5 No 2, 43-64, accessed on August 12, 2010

[9]. National Science Research Council. 2000. Inquiry and the National Science Education Standards .Washington, DC: National Academic Press.Available http://www.nap.edu/books/0309064767/html/, accessed on August 12, 2010.

[10]. Novak, JD 1998. Learning, creating, and using knowledge: Concept map and facilitative tools in schools and corporations. Mahwah, NJ: Lawrence Erlbaum Associates.

[11]. Patterson, ME, Dansereau, DF, \& Newbern, D. (1992). Effects of communication aids and strategies on cooperative teaching. Journal of Educational Psychology, 84 (4), 453-461.

[12]. Plass, Moreno, Brunken, 2010. Cognitive Load Theory. Cambridge University Press

[13]. Silver, et al. 2007. The Strategic Teacher: Selecting the Right Research Based Strategy for Every Lesson. ASCD. USA

[14]. Wash, AJ \& Sattes, DB 2005. Quality questioning: Research-based practice to engage every learner .London: Sage Publications Ltd. 
[15]. Wee, B., Shepardson, D., Fast, J. \& Harbor, J. 2007. Teaching and learning about inquiry: insights and challenges in professional development. Journal of science education teacher, 18, 63-89, accessed on 12 August 2010

[16]. Wenning, CJ 2005a. Levels of inquiry: hierarchies of pedagogical practices and inquiry processes. Journal of Physics Teacher Education Online, 2 (3), 3-11, accessed on August 12, 2010.

[17]. Wenning, CJ 2005b. Minimizing resistance to inquiry-oriented instruction: The importance of climate setting .Journal of Physics Teacher Education Online, 3 (2), 10-15. Available: http://phy.istu.edu/publications/minimizing resistance.pdf, accessed on August 29, 2010.

[18]. Wenning, CJ 2007. Assessing inquiry skills as a component of scientific literacy .Journal online Physics Teacher Education Vol 4 No 2, accessed on August 12, 2010. 